\title{
Perbedaan Perceived Restorativeness Antara Siswa Yang Bersekolah di Sekolah Alam Dengan Sekolah Umum
}

\author{
Johan Satria Putra \\ Universitas YARSI \\ johan.satria@yarsi.ac.id
}

\begin{abstract}
Perceived restorativeness is a recovery of an individual's condition from psychological fatigue as a result of daily activities. There are less space for children to interact with nature environment nowadays, which making perceived restorativeness decreases. One kind of school with natural elements that currently exists is Sekolah Alam (natural school), but the psychological research in Indonesia with these natural school objects is still rare. This study aims to examine the difference of perceived restorativeness between natural school and public school student. The study was conducted using comparative t-test techniques between the two groups of subjects. The instrument was the PRCSC-II scale. Data analyzing found that there were differences in perceived restorativeness between natural school and public schools students $(p<0.05)$, with the level of perceived restorativeness in public school students being higher than natural school students. This difference can be caused by several factors, including the neatness and the abundance of green elements in the school, the presence of peer groups, as well as the activities carried out at the place. It is expected that the results of this study may be applied, both by public schools and natural schools, to design a more restorative school environment.
\end{abstract}

Keywords: nature school; perceived restorativeness; public school

\begin{abstract}
ABSTRAK
Pengalaman restoratif atau perceived restorativeness adalah suatu pemulihan kondisi individu dari kelelahan psikologis sebagai akibat dari aktivitas sehari-hari. Ruang bagi anak untuk berinteraksi dengan alam dewasa ini semakin sedikit, sehingga perceived restorativeness menjadi menurun. Salah satu jenis sekolah yang ada saat ini yang memiliki unsur-unsur alami adalah sekolah alam, namun masih sangat sedikit penelitian psikologi di Indonesia dengan objek sekolah alam ini.. Penelitian ini bertujuan untuk melihat bagaimana perbedaan perceived restorativeness antara anak yang bersekolah di sekolah alam dengan anak yang bersekolah di sekolah umum. Penelitian dilakukan dengan pendekatan kuantitatif untuk melihat perbedaan perceived restorativeness antara dua kelompok subjek tersebut menggunakan teknik uji komparasi. Instrumen yang digunakan adalah skala PRCSC-II. Hasilnya ditemukan bahwa terdapat perbedaan perceived restorativeness antara siswa sekolah alam dengan sekolah umum $(\mathrm{p}<0,05)$, dengan tingkat perceived restorativeness pada siswa sekolah negeri lebih tinggi daripada siswa sekolah alam. Perbedaan ini dapat disebabkan oleh beberapa faktor, yaitu kerapian dan kelebatan elemen hijau di sekolah yang bersangkutan, keberadaan teman, serta aktivitas yang dilakukan di sekolah. Diharapkan dari hasil penelitian ini nantinya dapat diaplikasikan, baik oleh pihak sekolah umum maupun sekolah alam, untuk merancang lingkungan sekolah yang lebih restoratif.
\end{abstract}

Kata Kunci: perceived restorativeness; sekolah alam; sekolah umum

Submitted May 11, 2021 | Revised May 31, 2021 | Accepted Jun 04, 2021

\section{Pendahuluan}

Perkembangan sebuah kota juga berdampak pada berkurangnya Ruang Terbuka Hijau (RTH) di wilayah perkotaan. Siahaan (dalam Dwihatmojo, 2010) menyatakan telah terjadi penurunan RTH di DKI Jakarta dari 70\% pada tahun 1970 menjadi sekitar 10\% pada tahun 2010. Peraturan Daerah (Perda) nomor 6 tahun 1999 tentang rencana tata ruang wilayah (RTRW) mencanangkan sasaran RTH pada tahun 2010 adalah 13,94\% atau sekitar 9.544 ha dari luas wilayah Jakarta. Saat ini luas RTH hanya mencapai 9,67\% atau sekitar 6.623 ha. Hal ini menunjukkan dibutuhkannya sekitar 3.354 Ha untuk mencapai jumlah ruang terbuka hijau yang ideal bagi kota Jakarta.

Berkurangnya Ruang Terbuka Hijau (RTH) ini juga berdampak pada berkurangnya ruang anak untuk bermain dan berinteraksi dengan alam. Sejumlah hasil penelitian menunjukkan berkurangnya 
intensitas anak bermain di luar ruangan, salah satunya dikarenakan kemajuan teknologi, masalah keamanan, serta terbatasnya ruang dan kesempatan (Collado \& Corraliza, 2012). Berkurangnya paparan terhadap lingkungan alami ini dapat berakibat pada perilaku anak sehari-hari di antaranya berkurangnya kepedulian anak pada lingkungan. Kepedulian terhadap lingkungan antara lain didorong oleh adanya perasaan keterikatan dan ketertarikan dari individu terhadap lingkungan, perasaan bebas ketika berada di lingkungan, serta lepas dari tekanan sehari-hari. Berbagai unsur ini dapat disebut sebagai perceived restorativeness.

Perceived restorativeness atau dapat juga disebut pengalaman restoratif adalah suatu konstruk yang sedang banyak diteliti dalam ranah psikologi lingkungan dewasa ini. Kata 'restoration' dapat diartikan sebagai suatu proses pemulihan fisik dan psikologis dari stress serta kelelahan mental yang diperoleh dari aktivitas sehari-hari (Joye \& van den Berg, 2013). Proses ini berupaya mengembalikan berbagai sumber daya fisik, sosial, dan psikologis yang terkuras atau terkurangi dari berbagai aktivitas sehari-hari tersebut (Gilchrist, 2015). Suatu lingkungan dapat dikatakan sebagai lingkungan yang restoratif (restorative environment) apabila lingkungan tersebut dapat mengurangi kelelahan mental dan juga berbagai kerugian psikologis lain yang ada, serta dapat memicu pemulihan kondisi psikologis dan fisik (Kaplan, 1995; Joye \& van den Berg, 2013).

Menurut Joye dan van den Berg (2013) pengalaman restoratif adalah proses pemulihan dan pengembalian kemampuan yang telah berkurang akibat dari aktivitas sehari-hari. Pengalaman restoratif didapat dari interaksi manusia dengan lingkungan atau tempat yang memberikan efek restoratif. Terdapat empat dimensi dari pengalaman restoratif berdasarkan Attention Restoration Theory (Van den Berg, Jorgensen, \& Wilson, 2014)., yaitu : perasaan tertarik atau terpesona terhadap suatu tempat (fascination), perasaan seolah-olah berada di tempat yang berbeda dan jauh dari tempat aktivitas sehariharinya (being away), perasaan bebas dalam melakukan hal-hal yang ingin dilakukan di tempat tersebut (compatibility), dan rasa keterhubungan (extent).

Efek restoratif yang dirasakan pada diri anak dapat memberikan manfaat positif terhadap lingkungan di sekitar mereka, dimana anak akan lebih menunjukkan sikap peduli terhadap lingkungan di sekitar mereka (Collado \& Corraliza, 2015). Salah satu aplikasinya adalah pada lingkungan sekolah. Suatu lingkungan sekolah dikatakan memiliki ciri-ciri yang restoratif apabila memenuhi keempat dimensi yang telah disebutkan dalam paragraf sebelumnya.

Berdasarkan sejumlah penelitian (Van den Berg, Jorgensen, \& Wilson, 2014), lingkungan yang bersifat alami (nature environment) akan lebih memberikan efek restoratif dibandingkan dengan lingkungan buatan (built environment). Dalam dunia pendidikan atau sekolah, maka jenis sekolah yang dapat dikatakan memiliki lingkungan yang didominasi oleh unsur alami adalah sekolah alam. Sekolah alam merupakan sekolah yang pengajarannya banyak dilakukan di ruang terbuka, atau dengan kata lain tanpa dinding dan jendela (id.m.wikipedia.org). Model pembelajaran yang dipergunakan banyak menggunakan action learning atau langsung berpraktek dan berinteraksi.

Berbagai penelitian mengenai perceived restorativeness pada anak telah banyak dilakukan di luar negeri, seperti misalnya yang dilakukan oleh Collado dan Collariza (2011; 2012; 2015), Matsuoka (2010), atau Bagot (2004). Sementara di Indonesia sendiri, penelitian mengenai konstruk ini masih belum banyak dilakukan. Sejauh ini peneliti baru menemukan satu buah penelitian terkait lingkungan restorative di Indonesia, yaitu oleh Farasa dkk. (2016). Penelitian dengan subjek siswa sekolah alam sejauh ini di Indonesia sebagian besar cenderung lebih bertujuan menguji suatu model pembelajaran.

Perceived restorativeness atau pengalaman restoratif memiliki sejumlah manfaat yang cukup besar bagi manusia. Pengalaman restoratif dapat menghadirkan emosi dan mood positif di dalam diri individu, meningkatkan kebahagiaan dan well-being, sekaligus menurunkan tingkat stress (Joye \& van den Berg, 2013). Begitu pula bagi optimalisasi pembelajaran dan prestasi siswa. Suatu lingkungan sekolah yang restoratif dapat meningkatkan konsentrasi siswa dalam belajar dan secara tidak langsung meningkatkan 
prestasi belajar. Di samping itu, lingkungan semacam ini juga dapat meningkatkan kedisiplinan siswa (Gilchrist, 2015).

Sementara Corraliza, Collado, dan Bethelmy (2011) menemukan bahwa terpapar lingkungan sekolah yang alami dapat membantu siswa untuk lebih tahan terhadap tekanan atau stress yang dialami karena pelajaran atau sebab lain. Bagot (2004) dalam studinya menyimpulkan bahwa siswa yang banyak menghabiskan waktu di halaman sekolah yang besifat alami, akan merasakan pengalaman restoratif yang lebih tinggi daripada siswa yang lebih banyak berada di ruangan yang tertutup. Meski demikian, lingkungan alam dengan pepohonan yang terlalu terlalu lebat serta membuat tempat itu menjadi tertutup, justru dapat menyebabkan seseorang merasa tidak nyaman dan aman (Van den Berg, Jorgensen, \& Wilson, 2014).

Di sisi lain, pada dasarnya built environment juga dapat memberikan pengalaman restoratif, apabila lingkungan tersebut memiliki elemen yang bersifat restorative ataupun didesain berdasarkan prinsipprinsip restoratif. Misalnya dalam studi terdahulu peneliti (Putra, Arlinkasari, \& Caninsti, 2017) mengenai konsep lingkungan restoratif pada RPTRA, menemukan bahwa lingkungan yang restoratif tidak terbatas pada taman hijau, namun juga dapat pula dapat diterapkan pada bangunan yang memiliki komponen-komponen hayati dan dipadukan dengan properti buatan manusia yang didesain secara restoratif. Misalnya seperti tembok yang digambar dengan lukisan atau tekstur natural, arsitektur yang geometris, serta ruang yang cukup lega dan nyaman bagi anak untuk beraktivitas.

Di dalam mendesain lingkungan suatu sekolah non-alam, konsep restoratif tersebut dapat diaplikasikan dalam bentuk misalnya mengkonsep ruang kelas dengan jendela yang menghadap ke pemandangan yang natural, arsitektur gedung sekolah yang bergaya minimalis, serta banyaknya tanaman yang menghiasi area sekolah (Putra, Arlinkasari, \& Caninsti, 2017). Penelitian ini merupakan upaya lanjutan dari peneliti untuk lebih melihat bagaimana konsep perancangan lingkungan yang restoratif ini dapat memiliki dampak yang signifikan, khususnya dalam lingkungan pendidikan atau sekolah.

Berbagai hasil penelitian terdahulu menunjukkan bahwa suatu yang lingkungan yang restoratif memiliki sejumlah dampak positif bagi siswa. Sekolah alam merupakan jenis sekolah yang diasumsikan memiliki ciri yang restoratif. Namun, asumsi teoritis ini perlu diuji kembali, apalagi mengingat penelitian dengan tema restorativeness di dunia pendidikan belum banyak dilakukan di Indonesia. Salah satu cara yang dapat dilakukan adalah dengan memperbandingkannya dengan jenis sekolah yang bersifat built environment.

Oleh karena itu, penelitian ini bertujuan untuk melihat bagaimana perbedaan pengalaman restoratif yang dimiliki oleh siswa sekolah alam dengan siswa dari sekolah umum. Diharapkan hasil dari penelitian ini dapat dijadikan rujukan bagi sekolah alam untuk lebih memaksimalkan potensi restoratif yang dimiliki, serta menjadi pedoman dan dorongan bagi sekolah umum untuk memenuhi unsur-unsur restoratif dalam lingkungannya, sehingga dapat membantu siswa untuk lepas dari tekanan rutinitas dan lebih optimal dalam belajar.

\section{Metode Penelitian}

Populasi subjek dalam penelitian ini adalah siswa kelas 4 sampai 5 Sekolah Dasar yang ada di Jakarta Timur. Sampel diambil dengan menggunakan teknik cluster sampling (Hadi, 2015). Dalam pemilihan subjek ini, kriteria yang diambil adalah anak usia 0 9-12 tahun, serta bersekolah di salah satu antara sekolah alam atau sekolah umum. Pengumpulan data dilakukan dengan membagikan angket kepada para siswa di sekolah yang bersangkutan, dalam pengawasan dan dipandu oleh peneliti. Hasilnya diperoleh 96 orang sampel penelitian.

Penelitian ini menggunakan pendekatan kuantitatif, yang menggunakan skala sebagai instrumen pengumpul data. Skala yang dipergunakan dalam penelitian ini adalah Perceived restorativeness Components Scale for Children (PRCSC-II), yang diadaptasi dari penelitian Bagot, Kuo, dan Allen (2007). Skala ini 
mengukur lima komponen perceived restorativeness, yaitu fascination, being away physical, being away psychological, compatibility, dan extent. Alat tes ini terdiri atas 15 aitem.

Analisis data dilakukan dengan metode uji komparasi menggunakan teknik independent t-test, untuk melihat perbedaan skor perceived restorativeness antara kelompok siswa sekolah alam dengan kelompok siswa sekolah umum. Seluruh prosedur analisis data dilakukan dengan bantuan software JASP.

\section{Hasil dan Pembahasan}

Jumlah partisipan dalam penelitian ini adalah sebanyak 96 orang dari dua Sekolah Dasar, terdiri atas 46 orang subjek dari sekolah alam dan 50 orang subjek dari sekolah negeri. Mayoritas subjek dalam penelitian ini berjenis kelamin perempuan (57\%). Selanjutnya, untuk usia mayoritas subjek berusia 10 tahun, yaitu sebanyak 49\%. Partisipan dalam penelitian ini adalah siswa kelas IV dan V sekolah dasar dari SD Negeri Umum dan SD Alam. SD Umum yang menjadi lokasi penelitian adalah SDN Jatirahayu III dan II, sementara SD alam yang menjadi lokasi adalah Sekolah Alam Bekasi dan Sekolah Alam Cikeas. Adapun untuk data selengkapnya subjek penelitian dapat dilihat pada Tabel 1.

Tabel 1. Deskripsi Data

\begin{tabular}{|c|c|c|c|}
\hline Variabel & & Jumlah & Presentase \\
\hline Jenis & Sekolah & 46 & $48 \%$ \\
\hline \multirow[t]{3}{*}{ Sekolah } & Alam & & \\
\hline & Sekolah & 50 & $52 \%$ \\
\hline & Negeri & & \\
\hline Jenis & Laki-laki & 41 & $43 \%$ \\
\hline \multicolumn{4}{|l|}{ Kelamin } \\
\hline & Perempuan & 55 & $57 \%$ \\
\hline \multirow{4}{*}{$\begin{array}{c}\text { Usia } \\
\text { (tahun) }\end{array}$} & 9 & 18 & $19 \%$ \\
\hline & 10 & 47 & $49 \%$ \\
\hline & 11 & 26 & $27 \%$ \\
\hline & 12 & 5 & $5 \%$ \\
\hline
\end{tabular}

Analisis data dilakukan dengan menggunakan metode komparasi dengan 455eknik independent ttest, untuk melihat perbedaan perceived restorativeness antara siswa SD alam dengan SD umum. Hasil uji ttest menunjukkan terdapat perbedaan perceived restorativeness yang signifikan $(\mathrm{p}=0,014 ; \mathrm{p}<0,05)$ antara siswa sekolah SD alam dengan siswa SD umum. Dengan demikian, maka hipotesis (Ha) diterima. Berdasarkan mean atau rata-rata skor yang diperoleh, menunjukkan bahwa skor rata-rata siswa SD umum lebih tinggi dibandingkan skor rata-rata siswa SD alam, yaitu 43,4 berbanding 39,98. Artinya, tingkat perceived restorativeness yang dimiliki oleh siswa SD umum lebih tinggi daripada siswa SD alam.

Di samping itu, peneliti juga mencoba untuk melihat perbedaan perceived restorativeness antar kelompok subjek per dimensi dari perceived restorativeness. Dikarenakan pesebaran data per dimensi tidak normal, maka untuk uji komparasi per dimensi ini peneliti menggunakan metode Mann-Whitney. Pada dimensi yang pertama, yaitu fascination, ditemukan bahwa terdapat perbedaan $(\mathrm{p}=0,041 ; \mathrm{p}<0,05)$ antara siswa SD alam dengan SD umum untuk dimensi ini. Kemudian untuk dimensi compatibility ditemukan perbedaan yang sangat signifikan $(\mathrm{p}<0,01)$ antara siswa SD umum dengan alam. Demikian juga untuk dimensi extent $(\mathrm{p}<0,01)$. Sedangkan untuk dimensi being away, baik physical maupun psychological, tidak ditemukan perbedaan antara siswa SD alam dengan SD umum $(\mathrm{p}=0,075$ dan $\mathrm{p}=0,985 ; \mathrm{p}>0,05)$. Hasil analisis data selengkapnya dapat dilihat pada Tabel 2. 


\begin{tabular}{llll}
\multicolumn{4}{c}{ Tabel 2. Hasil Uji t-test } \\
\hline Variabel & Sig. & $\begin{array}{l}\text { Mean SD } \\
\text { Alam }\end{array}$ & $\begin{array}{l}\text { Mean SD } \\
\text { Negeri }\end{array}$ \\
\hline $\begin{array}{l}\text { Perceived } \\
\text { restorativeness }\end{array}$ & $\mathrm{p}<0,05$ & 39,98 & 43,4 \\
Fascination & $\mathrm{p}<0,05$ & & \\
Compatibility & $\mathrm{p}<0,01$ & & \\
Extent & $\mathrm{p}<0,01$ & & \\
$\begin{array}{l}\text { Being away } \\
\text { physical }\end{array}$ & $\mathrm{p}>0,05$ & & \\
$\begin{array}{l}\text { Being away } \\
\text { psychological }\end{array}$ & $\mathrm{p}>0,05$ & & \\
\hline
\end{tabular}

Hasil analisis data menunjukkan bahwa terdapat perbedaan perceived restorativeness antara siswa sekolah alam dengan sekolah umum $(\mathrm{p}=0,014 ; \mathrm{p}<0,05)$. Hasil ini sesuai dengan penelitian terdahulu yang dilakukan oleh Kinanthi dan Arlinkasari (2018) yang menemukan bahwa perbedaan paparan visual antara nature dan built environment memberikan efek restoratif yang berbeda juga bagi individu. Selain itu, temuan ini juga sesuai dengan perspektif perceptual fluency account (PFA), bahwa terdapat perbedaan efek restoratif yang ditimbulkan oleh lingkungan alami dan buatan (Van den Berg, Jorgensen, \& Wilson, 2014).

Di sisi lain, efek restoratif yang ditimbulkan ditemukan lebih besar pada siswa SD negeri daripada siswa SD alam, yaitu dengan rerata 43,4 dibanding 39,98. Hasil ini bertolak belakang dengan temuan penelitian Collado \& Corraliza (2015) yang menemukan bahwa berada di lingkungan alami dapat memberikan pengalaman restoratif pada anak, sekaligus keterikatan emosional pada alam tersebut. Begitu juga hasil penelitian Matsuoka (2010) yang menunjukkan bahwa siswa yang bersekolah di sekolah yang memiliki paparan fitur alami yang lebih banyak seperti pepohonan atau semak, akan memiliki prestasi belajar dan perencanaan akademik yang lebih baik dibandingkan dengan siswa dari sekolah yang hanya sedikit terpapar fitur alami.

Pada dasarnya, tingkat kealamiahan suatu lingkungan merupakan sebuah konstruk yang bersifat multidimensional (Sugiyama, 2004 dalam Ivarsson \& Hagerhall, 2008). Artinya, tidak semua lingkungan yang bersifat alami secara otomatis dapat memberikan kontribusi positif bagi pengalaman restoratif seseorang. Terkadang efek restorative tersebut dapat juga bergantung pada kerapian dari elemen alami yang bersangkutan. Apabila suatu elemen hijau atau alami pada suatu ekosistem seperti taman atau kebun tidak tertata secara rapi, maka hal tersebut justru dapat menurunkan tingkat kesukaan yang selanjutnya mampu mempengaruhi perceived restorativeness. Di samping itu, ekosistem semacam taman terkadang memiliki elemen-elemen yang justru tidak memiliki efek restoratif (Ivarsson \& Hagerhall, 2008). Hal ini juga didukung oleh hasil penelitian Van den Berg, Jorgensen, dan Wilson (2014) yang menemukan bahwa lingkungan hijau yang terlalu lebat dan tertutup dapat menimbulkan rasa tidak nyaman dana man, sekaligus menurunkan efek restoratifnya.

Hasil penelitian dari Korpela, Kytta, dan Hartig (2002) menemukan bahwa tidak semua anak menyukai suatu lingkungan dikarenakan oleh efek restoratif yang diberikan oleh lingkungan tersebut, dan hal itu sekaligus menjadikan suatu lingkungan yang bersifat alami tidak selalu menjadi pilihan tempat yang disukai. Terdapat beberapa faktor lain yang dapat menjadikan seorang anak merasakan efek restoratif atau regulasi emosi, antara lain seperti keberadaan teman dan pengawasan orang tua. Di samping itu, penelitian ini juga menemukan bahwa tempat di mana anak-anak dapat berolahraga lebih disukai oleh mereka daripada lingkungan alami. Dengan demikian, terdapat beberapa faktor yang memungkinkan siswa di sekolah negeri umum (yang memiliki lingkungan buatan) dalam penelitian ini memiliki perceived restorativeness yang lebih tinggi daripada siswa sekolah alam, yaitu tingkat kerapian elemen hijau, teman, serta aktivitas yang dilakukan. 


\section{Kesimpulan}

Berdasarkan hasil penelitian, maka ditemukan bahwa terdapat perbedaan perceived restorativeness antara siswa sekolah alam dengan siswa sekolah umum. Siswa sekolah umum memiliki tingkat perceived restorativeness yang lebih tinggi daripada siswa sekolah alam.

Penelitian mengenai psikologi lingkungan selanjutnya diharapkan dapat menggunakan pendekatan interdisipliner, seperti misalnya dengan ilmu teknik arsitektur, mengingat hasil penelitian ini menemukan pentingnya detail elemen desain dari lingkungan itu sendiri terhadap aspek psikologis individu di dalamnya.

Sementara itu, kepada berbagai lembaga dan institusi pendidikan, khususnya Sekolah Dasar, agar dapat merancang dan mengatur lingkungan sekolah yang sesuai dengan konsep lingkungan yang memiliki efek restoratif, demikian pula dengan aktivitas yang dilakukan di dalamnya. Hal ini berlaku baik bagi sekolah umum maupun sekolah alam.

\section{Daftar Pustaka}

Collado, S. \& Corraliza, J.A. (2015). Children's restorative experiences and self-reported environmental behaviors. Environment and Behavior, 47(1), 38-56.

Gilchrist, K. (2015). Promoting wellbeing through environment: the role of urban forestry. Parallel session 1b: Promoting green networks and buman wellbeing, 84-93. Retrieved 14 June 2017, from www.forestry.gov.uk.

Gillis, K. \& Gatersleben, B. (2015). A Review of psychological literature on the health and well-being benefits of biophilic design. Buildings, 5, 948-963.

Han, K.-T. (2003). A reliable and valid self-rating measure of the restorative quality of natural environments. Landscape and Urban Planning, 64, 209-232.

Hansmann, R., Hug, S., \& Seeland, K. (2007). Restoration and stress relief through physical activities in forests and parks. Urban forestry and Urban Greening, 6, 213-225.

Hartig, T. (2007). Three steps to understanding restorative environments as health resources. In: Thompson, C.W. \& Travlou, P. (eds). Open Space: People Space. pp.163-180.

Hartig, T., Korpela, K., Evans, G.W., \& Garling, T. (1996). Validation of measure of perceived environmental restorativeness. Goteborg Psychological Reports, 26, 1-64.

Iskandar, Tb.Z. (2012). Psikologi Lingkungan : Teori Dan Konsep. Bandung: Ikapi.

Ivarsson, C.T. \& Hagerhall, C.M. (2008). The perceived restorativeness of gardens - Assessing the restorativeness of a mixed built and natural scene type. Urban Forestry \& Urban Greening, 7, 107118.

Jaenudin, U. \& Marliani, R. (2017). Psikologi Lingkungan. Bandung: Pustaka Setia.

Joye, Y. \& Van den Berg, A.E. (2013). Restorative environments. In: Steg, L., Van den Berg, A.E., \& De Groot, J.I.M. (eds). Environmental Psychology, An Introduction. Oxford: Blackwell.pp.58-66.

Korpela, K., Kytta, M., \& Hartig, T. (2002). Restorative experience, self-regulation, and children's place preferences. Journal of Environmental Psychology, 22, 387-398.

Matsuoka, R. (2010). Student performance and high school landscapes: Examining the links. Landscape and Urban Planning, 97, 273-282.

Putra, J.S., Arlinkasari, F., \& Caninsti, R. (2017). How restorative is your surroundings? (and how it benefits you). $1^{\text {st }}$ International Conference on Urbanism and Religiosity Proceeding, 107-114, ISBN:978602-50886-05.

Tsunetsugu, y. Park, B.J., \& Miyazaki. (2010). Trends in research related to 'Shinrin-yoku' (taking in the forest atmosphere or forest bathing) in Japan. Environmental Health and Preventive Medicine, 15, 27 37. 
Tryvainen, L., et.al. (2014). The influence of urban green environments on stress relief measures: A field experiment. Journal of Environmental Psychology, 38, 1-9.

Van den Berg, A.E., Hartig, T., \& Staats, H. (2007). Preference for Nature In Urbanized Societies: Stress, Restoration, And The Pursuit Of Sustainability. Journal of Social Issues, 63 (1), 79-96.

Van den Berg, A.E., Jorgensen, A., \& Wilson, E.R. (2014). Evaluating restoration in urban green spaces: Does setting type make a difference? Landscape and Urban Planning, 127, 173-181. 